\title{
Effects of Baru Almond and Brazil Nut Against Hyperlipidemia and Oxidative Stress In Vivo
}

\author{
Daniela Canuto Fernandes ${ }^{1}$, Aline Medeiros Alves ${ }^{2}$, Gabriela Salim Ferreira Castro ${ }^{3}$, Alceu Afonso Jordão \\ Junior $^{3} \&$ Maria Margareth Veloso Naves ${ }^{2}$ \\ ${ }^{1}$ Pontifical Catholic University of Goiás, Department of Nursing, Nutrition and Physiotherapy, Goiânia, Goiás, \\ Brazil \\ ${ }^{2}$ Federal University of Goiás, School of Nutrition, Goiânia, Goiás, Brazil \\ ${ }^{3}$ University of São Paulo, School of Medicine, Ribeirão Preto, São Paulo, Brazil \\ Correspondence: Maria Margareth Veloso Naves, Federal University of Goiás, School of Nutrition, Rua 227, \\ Quadra 68, 74605-080, Goiânia, Goiás, Brazil. Tel: 55-62-3209-6270/214; Fax: 55-62-3209-6273. E-mail: \\ mmvnaves@gmail.com
}

Received: March 3, 2015 Accepted: April 17, 2015 Online Published: May 7, 2015

doi:10.5539/jfr.v4n4p38

URL: http://dx.doi.org/10.5539/jfr.v4n4p38

\begin{abstract}
This study evaluated the effect of baru (Dipteryx alata Vog.) almond, an edible seed native from Brazilian Savanna, and Brazil nut (Bertholletia excelsa H. B. K.) on serum lipid profile and hepatic lipid peroxidation in rats fed high-fat diets. Four groups of eight young adult male Wistar rats were treated for nine weeks with one of the following diets: high-fat diets $-0.1 \%$ colic acid $+1 \%$ cholesterol $+5 \%$ lard $+15 \%$ of lipid from lard, baru almond or Brazil nut - and reference diet (7\% soybean oil). Groups fed with baru almond and Brazil nut showed lower serum contents of total cholesterol and triacylglycerols than those of lard group. Baru almond group also showed higher HDL-c concentration than those of Brazil nut and lard groups, similar to that of reference group. Lipid peroxidation (through total malondialdehyde) was lower and vitamin E content was higher in the livers of the animals treated with baru almond and Brazil nut than those of lard group. These results indicate that the Brazilian native oilseeds, especially baru almond, have great potential for dietary use in dyslipidemia prevention and control.
\end{abstract}

Keywords: Bertholletia, Dipteryx, high-fat diet, lipid peroxidation, monounsaturated fat, rat

\section{Introduction}

The consumption of edible seeds and nuts has been associated with a reduction in cardiovascular diseases risk (Lee, Lavie, O'Keefe, \& Milani, 2011). Studies using experimental models of dyslipidemia have showed evidence in an improvement of serum lipid profile and antioxidant status in animals fed oilseeds, like peanut (Emekli-Alturfan, Kasikci, \& Yarat, 2007; Stephens, Dean, Davis, Osborne, \& Sanders, 2010), flaxseed (Cintra et al., 2006) and pistachio (Alturfan, Emekli-Alturfan, \& Uslu, 2009). Their beneficial effects on cardiovascular health are attributed to their high contents of unsaturated fatty acids, particularly monounsaturated acids. In addition, oilseeds are rich in antioxidant nutrients and other bioactive compounds, such as phenolics, which probably contribute to the decrease of cardiovascular diseases risk (Segura, Javierre, Lizarraga, \& Ros, 2006; Lee et al., 2011).

Even though edible seeds and nuts have high contents of unsaturated fat and bioactive compounds, there are remarkable differences among their chemical composition (Freitas \& Naves, 2010; Venkatachalam \& Sathe, 2006), which might generate different health effects. The baru almond (Dipteryx alata Vog) is an edible seed from Brazilian Savanna, and it is locally consumed in roasted form and as an ingredient of traditional and exotic dishes, but it has a relatively high cost, mainly due to its handmade conditions of harvesting and processing. Baru almond contains high amounts of monounsaturated fatty acids (MUFA), zinc and phenolic compounds (Marin, Siqueira, \& Arruda, 2009; Freitas \& Naves, 2010; Sousa, Fernandes, Alves, Freitas, \& Naves, 2011). On the other hand, Brazil nut (Bertholletia excelsa H.B.K.) is a true nut, which is produced in large scale and is consumed worldwide; consequently, it is cheaper than baru almond. It contains high levels of polyunsaturated fatty acids (PUFA) and selenium (Segura et al., 2006; Venkatachalam \& Sathe, 2006; Freitas \& Naves, 2010). 
The effect of baru almond and Brazil nut consumption on serum lipid profile and oxidative status has not been studied in animal model of dyslipidemia. Therefore, the aim of this study was to investigate the effect of these native Brazilian oilseeds on serum lipid profile and hepatic lipid peroxidation in animals treated with high-fat diets.

\section{Method}

\subsection{Fruit Collection and Sample Preparation Procedures}

Baru seed and Brazil nut were purchased locally in the city of Goiânia, GO, Brazil. Raw baru seeds were roasted at $140{ }^{\circ} \mathrm{C}$ for $30 \mathrm{~min}$ in an electric oven (Fernandes, Freitas, Czeder, \& Naves, 2010); then, they were peeled. Brazil nuts were purchased peeled and raw, because this nut is usually consumed in natura. The samples were ground in a multiprocessor and then used for chemical analyses and for formulation of the experimental diets.

\subsection{Chemical Composition of the Samples}

The following analyses were performed: moisture (Association of Official Analytical Chemists [AOAC], 2012); total nitrogen, according to the micro-Kjeldahl method and converted into protein using the factor 6.25 (AOAC, 2012); total lipids, extracted using the technique of Bligh and Dyer (1959) and subsequently estimated by gravimetry; ash, by burning in an oven at $550{ }^{\circ} \mathrm{C}$, and total dietary fiber (AOAC, 2012). Total carbohydrates were estimated by difference, subtracting the values obtained for moisture, protein, fat, ash and fiber from one hundred. The energy value of the samples was estimated based on the proximate composition data, considering the Atwater conversion factors, which are 4, 4, and $9 \mathrm{kcal} / \mathrm{g}$ for protein, carbohydrate, and lipid, respectively. The analyses were performed in triplicate.

\subsection{Antioxidant Nutrient Analysis}

Zinc was characterized and quantified, in triplicate, by atomic absorption spectrophotometry (Perkin Elmer Analyst-200 spectrometer). Samples were incinerated and then dissolved with concentrated hydrochloric acid (analytical grade). Specific instrumental parameters (lamp wavelength, lamp current and slit width) were used for the mineral analysis. Selenium was analyzed by atomic absorption spectrophotometry (HITACHI, model Z-5000, Tokyo) with generation of hydrides in a quartz tube (AOAC, 2012).

Vitamin E was estimated in the samples by $\alpha$-tocopherol analysis, according to Klejdus et al. (2004). Samples of baru almond and Brazil nut (approximately $2.0 \mathrm{~g}$ ) were weighed in conical centrifuge tubes. Then, $8 \mathrm{~mL}$ of absolute ethanol were added and it was stirred for approximately $30 \mathrm{~s}$ in a mixer, next $10 \mathrm{~mL}$ of distilled water were added and again stirred on vortex for $30 \mathrm{~s}$. Thereafter, $8 \mathrm{~mL}$ of hexane were added and stirred for $30 \mathrm{~s}$ on vortex. Afterwards, the samples were centrifuged at $3.500 \mathrm{rpm}$ for $5 \mathrm{~min}$. After centrifugation, the upper layer was taken and filtered (filter $0.45 \mathrm{mM}$ ). The standard curve was prepared from a solution with $\alpha$-tocopherol dissolved in methanol. The samples were injected in duplicate on HPLC apparatus (Gilson, Wisconsin, USA), in column ODS2 type, with $10 \mathrm{~cm} \times 4.6 \mathrm{~mm}$ (ES Industries, Berlin, Germany). The flow rate was $0.7 \mathrm{~mL} / \mathrm{min}$ and auto sampler injection was $3 \mu \mathrm{L}$.

\subsection{Fatty Acid Composition of the Samples}

To determine the fatty acid composition, the samples were extracted as described by Folch, Less and Stanley (1957) and esterified according to Hartman and Lago (1973). Fatty acids were separated by Finnigan Focus GC gas chromatography (Thermo, Austin, TX, USA) with a flame ionization detector and capillary column (RESTEK, Bellefonte, PA, USA - polyethylene glycol crossbond - $30 \mathrm{~m} \times 0.25 \mathrm{~mm}$ ) of fused silica. The running conditions were: carrier gas - hydrogen $(2 \mathrm{~mL} / \mathrm{min})$; make up gas - nitrogen $(28 \mathrm{~mL} / \mathrm{min})$; hydrogen $(30$ $\mathrm{mL} / \mathrm{min})$, and synthetic air $(300 \mathrm{~mL} / \mathrm{min})$ in order to maintain the detector flame. The injection volume was $1 \mu \mathrm{L}$ and split ratio of 2:98. Retention time, peak area, and area relative values were obtained using the Chrom Quest 4.1 software. Fatty acids were identified and quantified by reference to the calibration curve prepared with standard methyl esters of fatty acids (Sigma Aldrich). The analyses were performed in triplicate.

\subsection{Biological Assay}

The experiment was carried out with young adult male Wistar rats purchased from Bioagri Laboratories Experimental Animal Center (Federal District, Brazil). In the experiment, 32 rats were randomly divided into 4 groups ( $\mathrm{n}=8$ /group), whose averages of body weight $(218-239 \mathrm{~g})$ were not significantly different $(\mathrm{p}<0.05)$. The rats were kept in individual cages for 10 weeks (one week acclimation to the experimental facility and 9 weeks of assay), in a temperature-controlled room at $22 \pm 2{ }^{\circ} \mathrm{C}$ and under a $12: 12 \mathrm{~h}$ of light: dark photoperiod. All procedures with animals were conducted according to the guide for the care and use of laboratory animals (National Research Council, 2011), and were approved by the Ethics Committee on Animal Use of the Federal 
University of Goiás (Protocol n 153/08).

Three high-fat diets with similar contents of protein, lipid and energy, and a reference diet (7\% soybean oil) were prepared (Table 1), according to AIN-93G (Reeves, Nielsen, \& Fahey Junior, 1993). High-fat diets were formulated with 5\% lard (Sadia), $1 \%$ cholesterol (Sigma Aldrich) and $0.1 \%$ colic acid (Rhoster) (Cintra et al., 2006; Riediger et al., 2008), and 15\% lipid from lard, baru almond or Brazil nut. The chemical analysis of the diets was performed following the methods described in item 2.2. The total lipid concentration of the high-fat diets was around $20 \%$ (Table 1), reaching approximately three times the regular content of reference diet's lipid (Reeves et al., 1993).

At the end of nine weeks of experimentation, overnight-fasted animals were euthanized with a mixture of ketamine and xylazine $(0.2 \mathrm{~mL}$ per $100 \mathrm{~g}$ of body weight); blood samples were collected by heart puncture, and serum was taken after centrifugation at $2400 \mathrm{~g}$ for $15 \mathrm{~min}$. Liver tissue samples were collected and immediately stored at $-80{ }^{\circ} \mathrm{C}$ for further analyses.

Table 1. Ingredients and chemical composition of the experimental diets

\begin{tabular}{lllll}
\hline \multirow{2}{*}{ Component $(\mathrm{g} / 100 \mathrm{~g})$} & \multicolumn{2}{l}{ High-fat diet } & Reference \\
\cline { 2 - 5 } diet
\end{tabular}

Baru almond and Brazil nut were added to diets to supply $15 \mathrm{~g}$ of lipids $100 \mathrm{~g}$ of diet.

\subsection{Blood Lipids}

Total serum cholesterol (TC), triacylglycerol (TG) and high-density lipoprotein cholesterol (HDL-c) concentrations were analyzed using diagnostic kits (Labtest Diagnostics SA, Minas Gerais, Brazil).

\subsection{Hepatic Analyses}

Lipid peroxidation was estimated in the liver by the analysis of malondialdehyde (MDA), according to the method proposed by Gerard-Monnier et al. (1998). For that, $100 \mathrm{mg}$ of liver tissue were weighed and homogenized in $1 \mathrm{~mL}$ of $1 \% \mathrm{KCl}$ solution. Thereafter, $650 \mu \mathrm{L}$ of $10 \mathrm{mM}$ solution of 1-methyl-2-phenylindole in acetonitrile and methanol $(2: 1, \mathrm{v} / \mathrm{v})$ and $150 \mu \mathrm{L}$ of pure $\mathrm{HCl}(37 \%)$ were added to the homogenate. The vials were stirred on vortex and incubated in a water bath at $45{ }^{\circ} \mathrm{C}$ for $40 \mathrm{~min}$, centrifuged at $4000 \mathrm{rpm}$ for $15 \mathrm{~min}$, and the supernatant absorbance was read at a wavelength of $586 \mathrm{~nm}$ in a SpectraMax M-5 (Molecular Advices, 
California, USA). MDA concentration was calculated by constructing a hydrolyzed 1,1,3,3-tetramethoxypropane (TMP) curve.

Hepatic reduced glutathione (GSH) concentration was evaluated according to the method described by Sedlak and Lindsay (1968). Hepatic tissue protein concentration was determined by the biuret method, in order to correct the MDA and GSH results. Protein content was analyzed by a commercial kit (Labtest Diagnostics S.A., Minas Gerais, Brazil). Copper ions of biuret reagents react with peptide bonds of proteins resulting in a purple solution, which was read at $545 \mathrm{~nm}$ in a SpectraMax M-5.

The analysis of hepatic vitamin E was performed as described by Arnaud, Fortis, Blachier, Kia and Favier (1991). A sample of $200 \mathrm{mg}$ of liver tissue was weighted and $500 \mu \mathrm{L}$ of an ethanol, $\mathrm{NaOH}$ and BHT (butylated hydroxyl toluene) mixture were added. Then, samples were incubated in water bath at $50{ }^{\circ} \mathrm{C}$ for $40 \mathrm{~min}$, with subsequent stirring for $1 \mathrm{~min}$, and were centrifuged ( $5 \mathrm{~min}$ at $3500 \mathrm{rpm}$ ). Samples were dried in liquid nitrogen and frozen at $-80{ }^{\circ} \mathrm{C}$ until the time of injection in HPLC (column C-18 type, Shimpack CLC-ODS $4.6 \times 25 \mathrm{~cm}$ and flow rate of $2.0 \mathrm{~mL} / \mathrm{min}$ ). Concentration was calculated using internal and external standards of $\alpha$-tocopherol.

\subsection{Statistical Analysis}

Data were expressed as mean \pm standard deviation. Student's $t$ test was used for comparisons between baru almond and Brazil nut's composition. ANOVA followed by Tukey test was used for comparisons between experimental data. Differences were considered significant when $\mathrm{p}<0.05$. Data were analyzed using Statistica software (Stat Soft Inc, version 7, Tulsa, USA).

\section{Results}

Baru almond showed high content of vitamin $\mathrm{E}$ and low amounts of selenium, and Brazil nut showed high selenium concentration. Both baru almond and Brazil nut have high contents of zinc. Regarding the lipid profiles of the samples, baru almond has more MUFA (mainly oleic acid) than Brazil nut, which showed higher contents of saturated fatty acids (SFA) and PUFA (linoleic acid) than baru almond (Table 2).

After nine weeks on high-fat diets, body weights were similar between groups, except for the baru almond group, which showed the lowest final body weight compared to high-fat diet groups. However, it was similar to that of reference group (Table 3).

Animals fed high-fat diets containing baru almond or Brazil nut showed lower TC and TG serum concentrations than those of lard group $(\mathrm{p}<0.05)$. Compared to baru almond and reference groups, lard group's animals presented high TC and TG serum concentrations, as well as low HDL-c serum concentration, thus endorsing the dyslipidemia model (Table 3).

Brazil nut group showed a lower lipid peroxidation level than that of lard group; however, baru almond group had the lowest lipid peroxidation level among groups fed high-fat diet. The higher MDA value found in lard group, compared to the other groups, confirm the oxidative effect of dyslipidemic diets on liver tissue. Hepatic GSH concentrations were not different among high-fat diet groups, but hepatic vitamin E contents of the rats treated with baru almond and Brazil nut were higher than that of lard group (Table 3).

\section{Discussion}

Experimental studies have evaluated the effects of edible seeds and nuts on serum lipid profile (Cintra et al., 2006; Emekli-Alturfan et al., 2007; Alturfan et al., 2009). Nevertheless, this is the first study that investigated the effects of baru almond and Brazil nut on serum lipid profile and lipid peroxidation in animal model of high-fat diet. Brazil nut and baru almond consumption prevented hyperlipidemia and lipid peroxidation on liver tissue of rats fed high-fat diets, suggesting a protective role of these foods against the high intake of saturated fat and cholesterol.

The effect against hyperlipidemia observed in this study is probably related to the fatty acid profile of the Brazilian oilseeds, as they are rich in unsaturated fatty acids (baru almond $=70 \mathrm{~g} / 100 \mathrm{~g}$; Brazil nut $=77 \mathrm{~g} / 100 \mathrm{~g}$ total lipids). The content of unsaturated fatty acid in foods is inversely related to the serum cholesterol concentrations, as observed in the study of Mohamed, Hussein, Bhathena and Hafez (2002). In other study, hamsters treated for 24 weeks with a high-fat diet supplemented with peanuts, which is an edible seed rich in unsaturated fatty acid ( $82 \mathrm{~g} / 100 \mathrm{~g}$ total lipids (Freitas \& Naves, 2010), exhibited lowered concentrations of CT, LDL-c and VLDL-c, and lowered risk of developing atherosclerosis (Stephens et al., 2010). 
Table 2. Baru almond and Brazil nut's composition

\begin{tabular}{|c|c|c|}
\hline Content & Baru almond & Brazil nut \\
\hline \multicolumn{3}{|c|}{ Chemical composition $(\mathrm{g} / 100 \mathrm{~g})$} \\
\hline Moisture & $3.17 \pm 0.11^{\mathrm{a}}$ & $2.35 \pm 0.04^{\mathrm{b}}$ \\
\hline Protein & $28.94 \pm 0.30^{\mathrm{a}}$ & $13.36 \pm 0.03^{b}$ \\
\hline Total lipids & $42.40 \pm 0.65^{\mathrm{b}}$ & $65.13 \pm 0.98^{\mathrm{a}}$ \\
\hline Carbohydrates & 10.79 & 6.05 \\
\hline Total dietary fiber & $11.70 \pm 0.20^{\mathrm{a}}$ & $9.53 \pm 0.06^{\mathrm{b}}$ \\
\hline Soluble fiber & $2.40 \pm 0.10^{\mathrm{a}}$ & $1.50 \pm 0.00^{\mathrm{b}}$ \\
\hline Insoluble fiber & $9.30 \pm 0.10^{\mathrm{a}}$ & $8.03 \pm 0.06^{b}$ \\
\hline Ash & $3.01 \pm 0.04^{\mathrm{b}}$ & $3.58 \pm 0.02^{\mathrm{a}}$ \\
\hline Energy (kcal/100 g) & $574.01 \pm 6.15^{\mathrm{b}}$ & $663.81 \pm 4.98^{\mathrm{a}}$ \\
\hline \multicolumn{3}{|c|}{ Antioxidant nutrient $(\mathrm{mg} / 100 \mathrm{~g})$} \\
\hline Vitamin E & $21.40 \pm 1.40^{\mathrm{a}}$ & $5.96 \pm 0.11^{\mathrm{b}}$ \\
\hline Zinc & $6.74 \pm 0.04^{\mathrm{b}}$ & $7.52 \pm 0.20^{\mathrm{a}}$ \\
\hline Selenium & $0.26 \pm 0.03^{b}$ & $100.81 \pm 11.07^{\mathrm{a}}$ \\
\hline \multicolumn{3}{|c|}{ Fatty acid (g/100 g total lipids) } \\
\hline $\mathrm{C} 12: 0$ & $0.12 \pm 0.01$ & not detected \\
\hline C14:0 & $0.18 \pm 0.03^{\mathrm{a}}$ & $0.04 \pm 0.00^{\mathrm{b}}$ \\
\hline $\mathrm{C} 16: 0$ & $5.94 \pm 0.48^{b}$ & $14.15 \pm 0.03^{\mathrm{a}}$ \\
\hline $\mathrm{C} 17: 0$ & $0.04 \pm 0.00$ & $0.06 \pm 0.00$ \\
\hline C18:0 & $5.42 \pm 0.26^{\mathrm{b}}$ & $7.99 \pm 0.34^{\mathrm{a}}$ \\
\hline $\mathrm{C} 20: 0$ & $1.27 \pm 0.03^{\mathrm{a}}$ & $0.09 \pm 0.00^{\mathrm{b}}$ \\
\hline $\mathrm{C} 24: 0$ & not detected & $0.09 \pm 0.00$ \\
\hline Total SFA & $12.98 \pm 0.76^{b}$ & $22.43 \pm 0.37^{\mathrm{a}}$ \\
\hline $\mathrm{C} 17: 1$ & $0.05 \pm 0.01$ & not detected \\
\hline C18:1 & $41.41 \pm 2.08^{\mathrm{a}}$ & $33.66 \pm 0.33^{b}$ \\
\hline C20:1 & $0.13 \pm 0.00$ & not detected \\
\hline C24:1 & $3.90 \pm 0.08^{\mathrm{a}}$ & $0.07 \pm 0.01^{\mathrm{b}}$ \\
\hline Total MUFA & $45.49 \pm 2.01^{\mathrm{a}}$ & $33.74 \pm 0^{3.32^{b}}$ \\
\hline C18:2 & $24.40 \pm 1.31^{\mathrm{b}}$ & $43.77 \pm 0.04^{\mathrm{a}}$ \\
\hline C18:3 & not detected & not detected \\
\hline C20:2 & $0.10 \pm 0.02$ & not detected \\
\hline $\mathrm{C} 22: 6$ & $0.29 \pm 0.02$ & not detected \\
\hline Total PUFA & $24.79 \pm 1.31^{b}$ & $43.77 \pm 0.04^{\mathrm{a}}$ \\
\hline
\end{tabular}

Data are mean \pm standard deviation of 3 replicates. ${ }^{a, b}$ Different letters in the same row indicate significant difference $(p<0.05)$ by Student's $t$ test. SFA: saturated fatty acids; MUFA: monounsaturated fatty acids; PUFA: polyunsaturated fatty acids.

Beyond the protective effect of the two oilseeds tested in the present study, baru almond showed better effects on serum lipid profile and lipid peroxidation than Brazil nut, since the animals fed with baru almond had higher serum HDL-c concentration, similar to that of the reference group, and lower hepatic MDA content than those of Brazil nut (Table 3). These differences might be related to the fatty acid profiles of these foods, especially by the high MUFA contents of baru almond (Table 2). The consumption of peanuts, which is also an edible seed with 
high MUFA contents (Freitas \& Naves, 2010), improved HDL-c concentrations in rats treated for 12 weeks with a hyperlipidemic diet (Emekli-Alturfan et al., 2007). MUFA, especially oleic acid, have an important role in HDL-c increase, and the enrichment of lipoproteins with MUFA increases their resistance to oxidation, as MUFA is less prone to oxidation than PUFA (Cintra et al., 2006; Freitas \& Naves, 2010; Lee et al., 2011). Furthermore, PUFA, especially linoleic acid, are associated with increased synthesis of pro-inflammatory molecules, such as IL-10, which can reduce HDL-c concentrations (Kris-Etherton \& Yu, 1997; Moraitis et al., 2015), as observed in this study for Brazil nut. The baru almond fatty acid profile is being reported for the first time in our study, and the Brazil nut fatty acid profile described in this paper is consistent with the literature (Venkatachalam \& Sathe, 2006; Freitas \& Naves, 2010).

Table 3. Wistar rat's body weight, diet and lipid intakes, serum lipid profile and hepatic parameters after nine weeks of treatment with high-fat diets containing baru almond or brazil nut in comparison to lard and reference diets

\begin{tabular}{|c|c|c|c|c|}
\hline & \multicolumn{3}{|l|}{ High-fat diet } & \multirow{2}{*}{ Reference diet } \\
\hline & Lard & Baru almond & Brazil nut & \\
\hline \multicolumn{5}{|l|}{ Body weight (g) } \\
\hline final & $367.38 \pm 26.33^{\mathrm{a}}$ & $300.03 \pm 22.55^{\mathrm{b}}$ & $361.92 \pm 34.90^{\mathrm{a}}$ & $336.93 \pm 32.97^{\mathrm{a}, \mathrm{b}}$ \\
\hline gain & $128.12 \pm 24.85^{\mathrm{a}}$ & $68.50 \pm 8.80^{\mathrm{b}}$ & $126.88 \pm 28.35^{\mathrm{a}}$ & $119.00 \pm 7.26^{\mathrm{a}}$ \\
\hline \multicolumn{5}{|l|}{ Total intake (g) } \\
\hline diet & $1003.40 \pm 65.75^{\mathrm{a}, \mathrm{b}}$ & $908.37 \pm 57.89^{\mathrm{b}}$ & $1051.65 \pm 70.40^{\mathrm{a}}$ & $1169.80 \pm 94.65^{\mathrm{a}}$ \\
\hline lipid & $198.87 \pm 13.03^{\mathrm{a}}$ & $184.31 \pm 11.75^{\mathrm{a}}$ & $212.12 \pm 14.20^{\mathrm{a}}$ & $76.24 \pm 8.22^{\mathrm{b}}$ \\
\hline \multicolumn{5}{|l|}{ Serum lipid $(m g / d L)$} \\
\hline $\mathrm{TC}$ & $217.50 \pm 5.62^{\mathrm{a}}$ & $126.50 \pm 11.21^{\mathrm{b}}$ & $119.33 \pm 11.50^{\mathrm{b}}$ & $57.67 \pm 8.08^{\mathrm{c}}$ \\
\hline TG & $223.38 \pm 3.00^{\mathrm{a}}$ & $60.67 \pm 1.53^{\mathrm{c}}$ & $57.00 \pm 2.31^{\mathrm{c}}$ & $71.00 \pm 1.73^{b}$ \\
\hline HDL-c & $24.25 \pm 0.96^{\mathrm{b}}$ & $36.33 \pm 1.43^{\mathrm{a}}$ & $23.00 \pm 3.16^{\mathrm{b}}$ & $38.50 \pm 3.78^{\mathrm{a}}$ \\
\hline \multicolumn{5}{|l|}{ Hepatic parameter } \\
\hline MDA (mmol/g protein) & $345.69 \pm 7.99^{\mathrm{a}}$ & $92.31 \pm 7.80^{\mathrm{c}}$ & $153.65 \pm 15.32^{\mathrm{b}}$ & $71.20 \pm 2.17^{\mathrm{d}}$ \\
\hline GSH ( $\mu$ mol/g protein $)$ & $1.32 \pm 0.16^{\mathrm{b}}$ & $1.78 \pm 0.18^{\mathrm{b}}$ & $1.58 \pm 0.45^{\mathrm{b}}$ & $5.06 \pm 0.33^{\mathrm{a}}$ \\
\hline Vitamin $\mathrm{E}(\mu \mathrm{mol} / \mathrm{g}$ tissue $)$ & $7.22 \pm 0.01^{\mathrm{c}}$ & $10.81 \pm 1.31^{\mathrm{b}}$ & $11.62 \pm 0.62^{\mathrm{b}}$ & $15.88 \pm 0.61^{\mathrm{a}}$ \\
\hline
\end{tabular}

The higher contents of hepatic vitamin E observed in the animals' livers of baru almond and Brazil nut groups than that of lard group are probably associated to their lowered hepatic lipid peroxidation, estimated by MDA (Table 3). Vitamin E, especially as $\alpha$-tocopherol, may block the initiation and inhibit the propagation of lipid peroxidation, as an effective in vivo antioxidant (Kurtoglu et al., 2008; Niki, 2014). The role of vitamin $E$ in the reduction of lipid peroxidation has been confirmed in the literature, since the supplementation with $\alpha$-tocopherol $(100 \mathrm{IU} / \mathrm{kg})$ in animals fed high-fat diet for 20 weeks was associated to significant reduction in serum and hepatic MDA concentrations (Kim et al., 2013). In addition to its antioxidant role, $\alpha$-tocopherol may act in the regulation of genes related to lipids uptake (Azzi et al., 2004), as well as in transcription factors involved in fat metabolism, as the peroxisome proliferator-activated receptors (PPAR) (Yu et al., 2003). On the other hand, hepatic GSH concentrations were not different between the high-fat diet groups (Table 3). One possible explanation for the lower GSH levels in animals treated with baru almond and Brazil nut would be related to the GSH utilization in vitamin E recovery. Glutathione has important role on neutralizing peroxides and on the protection of cells against oxidative stress (Niki, 2014).

Although it is known that PUFA are more prone to oxidation than MUFA, edible seeds and nuts are rich in antioxidants that may protect those fatty acids from oxidative damage (Lee et al., 2011). This effect has been observed in experimental studies, since peanut and pistachio consumption improved the oxidative balance in rats 
fed high-fat diets (Emekli-Alturfan et al., 2007; Alturfan et al., 2009). Baru almond is rich in vitamin E and Brazil nut is the richest dietary source of selenium (Table 2). Therefore, the present study's data may be explained by the synergic effect of the fatty acid profiles, antioxidant micronutrients, and probably other compounds present in these foods, like phenolics (Venkatachalam \& Sathe, 2006; Marin, Siqueira, \& Arruda, 2009; Lee et al., 2011; Sousa et al., 2011). A study using baru almond in animal model reported that the consumption of baru seed protected the animals' tissues against iron supplementation-induced oxidative stress, and the authors suggest that the baru almond's phytic acid content was partially responsible for this antioxidant effect (Siqueira et al., 2012).

Even though oilseeds are high-energy foods, their consumption is not associated with weight gain (Martínez-González \& Bes-Rastrollo, 2011). According to Mattes and Dreher (2010), intake of edible seeds and nuts promotes satiety, especially due to their significant content of proteins and fibers, coupled with the need for intensive chewing upon consumption. Some authors also suggest that the intake of those foods is associated with an increase in energy expenditure or thermogenesis (Casas-Agustench et al., 2011). Therefore, the lower food consumption and body weight gain of baru almond group (Table 3) might be related to baru almond's higher contents of protein and fiber than those of Brazil nut (Table 2), and to the higher concentration of baru almond $(35 \mathrm{~g} / 100 \mathrm{~g})$ than Brazil nut $(23 \mathrm{~g} / 100 \mathrm{~g})$ in the experimental diets (Table 1). The daily energy consumption of baru almond group (69 kcal) was lower than that of Brazil nut group $(80 \mathrm{kcal})$, and the energy intake of lard group was similar to that of reference group $(76 \mathrm{kcal} / \mathrm{d})$, which justify the similar body weight gain of these two last groups (Table 3).

In previous studies with humans, the supplementation with Brazil nut did not increase the serum HDL-c concentration of normolipidemic subjects (Strunz, Oliveira, Vinagre, Lima, \& Cozzolino, 2008), but this effect was observed in obese women with dyslipidemia (Cominetti, Bortoli, Garrido Jr., \& Cozzolino, 2012). These data suggest that the effects of Brazil nut against dyslipidemia may be more evident in pathologic conditions. Concerning baru almond, a daily consumption of $20 \mathrm{~g}$ for 6 weeks decreased serum total cholesterol, LDL-c and non-HDL-c in mildly hypercholesterolemic individuals (Bento et al., 2014). Data of the present study and of the literature justify further investigations in order to clarify the role of these Brazilian oilseeds on prevention and treatment of dyslipidemia.

Overall, our data suggest that the consumption of baru almond and Brazil nut has a potential protective role against hyperlipidemia and lipid peroxidation. Nevertheless, the protective effect of baru almond was the most evident, since its consumption improved HDL-c concentrations and greatly decreased lipid peroxidation. Based on our results, these foods, especially baru almond, have a potential use in healthy diets, aiming at reducing hyperlipidemia and preventing related chronic diseases.

\section{Conclusions}

Baru almond and Brazil nut improve serum lipid profile and protect against oxidative stress in an animal model of dyslipidemia. These beneficial effects are more evident for baru almond than for Brazil nut. The high contents of monounsaturated fatty acid of baru almond may be related to the antidyslipidemic effect observed in this study. Therefore, baru almond has great potential for dietary use in dyslipidemia prevention and control.

\section{Acknowledgments}

The authors would like to thank Capes-MEC and UFG for financial support.

\section{References}

Alturfan, A. A., Emekli-Alturfan, E., \& Uslu, E. (2009). Consumption of pistachio nuts beneficially affected blood lipids and total antioxidant activity in rats fed a high-cholesterol diet. Folia Biologica, 55(4), 132-136. http://dx.doi.org/10.1016/0378-4347(91)80476-S

Association of Official Analytical Chemists. (2012). Official Methods of Analysis (19th ed.). Gaithersburg: AOAC International.

Arnaud, J., Fortis, I., Blachier, S., Kia, D., \& Favier, A. (1991). Simultaneous determination of retinol, alphatocopherol and beta-carotene in serum by isocratic high-performance liquid chromatography. Journal of Chromatography, 572(1-2), 103-116.

Azzi, A., Gysin, R., Kempná, P., Munteanu, A., Villacorta, L., Visarius, T., \& Zing, J. M. (2004). Regulation of gene expression by $\alpha$-tocopherol. Biological Chemistry, 385(7), 585-591. http://dx.doi.org/10.1515/BC.2004.072

Bento, A. P. N., Cominetti, C., Simões Filho, A., \& Naves, M. M. V. (2014). Baru almond improves lipid profile 
in mildly hypercholesterolemic subjects: A randomized, controlled, crossover study. Nutrition, Metabolism \& Cardiovascular Diseases, 24(12), 1330-1336. http://dx.doi.org/10.1016/j.numecd.2014.07.002

Bligh, E. G., \& Dyer, W. J. (1959). A rapid method of total lipid extraction and purification. Canadian Journal of Biochemistry and Physiology, 37(8), 911-917. http://dx.doi.org/10.1139/o59-099

Casas-Agustench, P., López-Uriarte, P., Bulló, M., Ros, E., Cabré-Vila, J. J., \& Salas-Salvadó, J. (2011). Effects of one serving of mixed nuts on serum lipids, insulin resistance and inflammatory markers in patients with the metabolic syndrome. Nutrition, Metabolism and Cardiovascular Diseases, 21(2), 126-135. http://dx.doi.org/10.1016/j.numecd.2009.08.005

Cintra, D. E. C., Costa, A. G. V., Peluzio, M. C., Matta, S. L. P., Silva, M. T. C., \& Costa, N. M. B. (2006). Lipid profile of rats fed high-fat diets based on flaxseed, peanut, trout or chicken skin. Nutrition, 22(2), 197-205. http://dx.doi.org/10.1016/j.nut.2005.09.003

Cominetti, C., Bortoli, M. C., GarridoJr, A. B., \& Cozzolino, S. M. F. (2012). Brazilian nut consumption improves selenium status and glutathione peroxidase activity and reduces atherogenic risk in obese women. Nutrition Research, 32(6), 403-407. http://dx.doi.org/10.1016/j.nutres.2012.05.005

Emekli-Alturfan, E., Kasikci, E., \& Yarat, A. (2007). Peanuts improve blood glutathione, HDL-cholesterol level and change tissue factor activity in rats fed a high-cholesterol diet. European Journal of Nutrition, 46(8), 476-482. http://dx.doi.org/10.1007/s00394-007-0688-1

Fernandes, D. C., Freitas, J. B., Czeder, L. P., \& Naves, M. M. V. (2010). Nutritional composition and protein value of the baru (Dipteryx alata Vog.) almond from the Brazilian Savanna. Journal of the Science of Food and Agriculture, 90(10), 1650-1655. http://dx.doi.org/10.1002/jsfa.3997

Folch, J., Less, M., \& Stanley, G. H. S. (1957). A simple method for the isolation and purification of total lipides from animal tissues. The Journal of Biological Chemistry, 226(1), 497-509.

Freitas, J. B., \& Naves, M. M. V. (2010). Composiçãoquímica de nozes e sementescomestíveis e suarelação com $\begin{array}{lllll}\text { a nutrição e } & \text { saúde.Revista de 23(2), } & \text { 269-279. }\end{array}$ http://dx.doi.org/10.1590/S1415-52732010000200010

Gerard-Monnier, D., Erdelmeier, I., Regnard, K., Moze-Henry, N., Yadan, J. C., \& Chaudiere, J. (1998). Reactions of 1-methyl-2-phenylindole with malondialdehyde and 4-hydroxyalkenals: analytical applications to a colorimetric assay of lipid peroxidation. Chemical Research in Toxicology, 11(10), 1176-1183. http://dx.doi.org/10.1021/tx9701790

Hartman, L., \& Lago, R. C. A. (1973).Rapid preparation of fatty acids methyl esters from lipids. Laboratory Practice, 22(6), 475-476.

Kim, D. Y., Kim, J., Ham, H. J., \& Choue, R. (2013). Effects of d- $\alpha$-tocopherol supplements on lipid metabolism in a high-fat diet-fed animal model. Nutrition Research and Practice, 7(6), 481-487. http://dx.doi.org/10.4162/nrp.2013.7.6.481

Klejdus, B. I., Petrlová, J., Sil, D. P., Adam, V. C., Mikelová, R., Vacek, J., ... Kubán, V. (2004). Simultaneous determination of water- and fat-soluble vitamins in pharmaceutical preparations by high-performance liquid chromatography coupled with diode array detection. Analytica Chimica Acta, 520(1-2), 57-67. http://dx.doi.org/10.1016/j.aca.2004.02.027

Kris-Etherton, P. M., \& Yu, S. (1997). Individual fatty acid effects on plasma lipids and lipoproteins: human studies. American Journal of Clinical Nutrition, 65(suppl), S1628-S1644.

Kurtoglu, F., Kurtoglu, V., \& Sivrikaya, A. (2008). Effects of vitamin E supplementation on antioxidant and lipid profiles of rats on diets supplemented with cholesterol and olive oil. Asian-Australasian Journal of Animal Sciences, 21(6), 883-889. http://dx.doi.org/10.5713/ajas.2008.70613

Lee, J. H., Lavie, C. J., O'Keefe, J. H., \& Milani, R. (2011). Nuts and seeds in cardiovascular health. In V. R. Preedy, R. R. Watson, \& V. B. Patel (Eds.), Nuts and Seeds in Health and Disease Prevention (pp. 75-82). London: Academic Press. http://dx.doi.org/10.1016/B978-0-12-375688-6.10008-8

Marin, A. M. F., Siqueira, E. M. A., \& Arruda, S. F. (2009). Minerals, phytic acid and tannin contents of 18 fruits from the Brazilian savanna. International Journal of Food Sciences and Nutrition, 60(suppl 7), 180-190. http://dx.doi.org/10.1080/09637480902789342

Martínez-González, M. A., \& Bes-Rastrollo, M. (2011). Nut consumption, weight gain and obesity: epidemiological evidence. Nutrition, Metabolism and Cardiovascular Diseases, 21 (suppl 1), S40-S45. http://dx.doi.org/10.1016/j.numecd.2010.11.005 
Mattes, R. D., \& Dreher, M. L. (2010). Nuts and healthy body weight maintenance mechanisms. Asia Pacific Journal of Clinical Nutrition, 19(1), 137-141.

Mohamed, A. I., Hussein, A. H., Bhathena, S. J., \& Hafez, Y. S. (2002). The effect of dietary menhaden, olive, and coconut oil fed with three levels of vitamin E on plasma and liver lipids and plasma fatty acid composition in rats. The Journal of Nutritional Biochemistry, 13(7), 435-441. http://dx.doi.org/10.1016/S0955-2863(02)00196-1

Moraitis, A. G., Freeman, L. A., Shamburek, R. D., Wesley, R., Wilson, W., Grant, C. M., ... Remaley, A. T. (2015). Elevated interleukin-10: a new cause of dyslipidemia leading to severe HDL deficiency. Journal of Clinical Lipidology, 9(1), 81-90. http://dx.doi.org/10.1016/j.jacl.2014.09.014

Niki, E. (2014). Role of vitamin E as a lipid-soluble peroxyl radical scavenger: in vitro and in vivo evidence. Free Radical Biology \& Medicine, 66, 3-12. http://dx.doi.org/10.1016/j.freeradbiomed.2013.03.022

National Research Council. (2011). Guide for the Care and Use of Laboratory Animals. Washington, DC: National Academy Press.

Reeves, P. G., Nielsen, F. N., \& Fahey Junior, G. C. (1993). AIN-93 purified diets for laboratory rodents: final report of the American institute of nutrition ad hoc writing committee on the reformulation of the AIN-76A rodent diet. The Journal of Nutrition, 123(11), 1939-1951.

Riediger, N. D., Othman, R., Fitz, E., Pierce, G. N., Suh, M., \& Moghadasian, M. H. (2008). Low n-6:n-3 fatty acid ratio, with fish- or flaxseed oil, in a high fat diet improves plasma lipids and beneficially alters tissue fatty acid composition in mice. European Journal of Nutrition, 47(3), 153-160. http://dx.doi.org/10.1007/s00394-008-0709-8

Sedlak, J., \& Lindsay, R. H. (1968). Estimation of total protein bound and nonproteinsulfydryl groups in tissue $\begin{array}{llll}\text { with Ellman's } \quad \text { reagent. } & \text { Analytical }\end{array}$ http://dx.doi.org/10.1016/0003-2697(68)90092-4

Segura, R., Javierre, C., Lizarraga, M. A., \& Ros, E. (2006). Other relevant components of nuts: phytosterols, folate and minerals. The British Journal of Nutrition, 96(suppl 2), S36-S44. http://dx.doi.org/10.1017/BJN20061862

Siqueira, E. M. A., Marin, A. M. F., Cunha, M. S. B., Fustinoni, M. A., Sant'Ana, L. P., \& Arruda, S. F. (2012). Consumption of baru seeds (Dipteryx alata Vog.), a Brazilian savanna nut, prevents iron-induced oxidative stress in rats. Food Research International, 45(1), 427-433. http://dx.doi.org/10.1016/j.foodres.2011.11.005

Sousa, A. G. O., Fernandes, D. C., Alves, A. M., Freitas, J. B., \& Naves, M. M. V. (2011). Nutritional quality and protein value of exotic almonds and nut from Brazilian Savanna compared to peanut. Food Research International, 44(7), 2319-2325. http://dx.doi.org/10.1016/j.foodres.2011.02.013

Stephens, A. M., Dean, L. L., Davis, J. P., Osborne, J. A., \& Sanders, T. H. (2010). Peanuts, peanut oil, and fat free peanut flour reduced cardiovascular disease risk factors and the development of atherosclerosis in syrian golden hamsters. Journal of Food Science, 75(4), 116-122. http://dx.doi.org/10.1111/j.1750-3841.2010.01569.x

Strunz, C. C., Oliveira, T. V., Vinagre, J. C., Lima, A., \& Cozzolino, S. (2008). Brazil nut ingestion increased plasma selenium but had minimal effects on lipids, apolipoproteins, and high-density lipoprotein function in human subjects. Nutrition Research, 28(3), 151-155. http://dx.doi.org/10.1016/j.nutres.2008.01.004

Venkatachalam, M., \& Sathe, S. K. (2006). Chemical composition of selected edible nut seeds. Journal of Agricultural and Food Chemistry, 54(13), 4705- 4714. http://dx.doi.org/10.1021/jf0606959

Yu, S., Matsusue, K., Kashireddy, P., Cao, W. Q., Yeldandi, V., Yeldandi, A. V., ... Reddy, J. K. (2003). Adipocyte-specific gene expression and adipogenicsteatosis in the mouse liver due to peroxisome proliferator-activated receptor gamma1 (PPAR gamma1) overexpression. The Journal of Biological Chemistry, 278(1), 498-505. http://dx.doi.org/10.1074/jbc.M210062200

\section{Copyrights}

Copyright for this article is retained by the author(s), with first publication rights granted to the journal.

This is an open-access article distributed under the terms and conditions of the Creative Commons Attribution license (http://creativecommons.org/licenses/by/3.0/). 